\title{
MUTUAL ORGANIZATIONS, MUTUAL SOCIETIES
}

\author{
By Edith Archambault, \\ Centre d'économie de la Sorbonne \\ Université Paris1 Panthéon-Sorbonne
}

\section{INTRODUCTION}

Mutual organizations or mutual societies, often designated as mutuals, exist everywhere in the world, in developing as well as in industrialized countries, on a more or less institutionalized form. In a developing country, some mutual organizations appear as voluntary associations for gathering and pooling money to fund marriages, funerals or a business start-up for one or several members (tontines). Other mutuals pool voluntary work to afford water supplies or build roads in rural areas (development self-help associations). In a developed country mutual societies are businesses; they operate in the same markets as corporations and compete with them. They are formed on a voluntary basis to provide aid, benefits, insurance, credit or other services either to their members or to a larger population. In many countries mutual organizations have a very remote historical background as said hereafter.

According to a very large definition of the European Commission in 2003, mutual organizations/societies "are voluntary groups of persons (natural or legal) whose purpose is primarily to meet the needs of their members rather than achieve a return on investment". This large definition includes self-help groups, friendly societies, cooperatives, mutual insurance companies, mutual benefit societies, credit unions, building societies, savings and loans associations, micro-credit, burial associations, Freemasons... Hereafter, it is a more restricted definition that is used, relying on principles shared by most mutuals in Europe, the region where they are the most widespread: 102 million members, 168 million of beneficiaries (AIM 2008). However some international examples put European mutual societies in perspective.

As operating on the same markets as corporations, mutual societies are facing a global competition challenging their historical values. As forerunners or complements to the social security schemes, they have to find innovating responses to new social needs and to the crisis of the welfare state. These key issues and new challenges are at the roots of the dynamics of mutual organizations

\section{DEFINITION}

The core organizations examined here will be mutual insurance companies and mutual benefit societies. In that sense mutual societies are insurance companies run by their members for protecting them against property, personal and social risks on a voluntary and noncompulsory basis. Mutual insurance companies deal with property and life risks while mutual benefit societies protect their members against the social risks: illness, disability and old age mainly.

The definition above quoted has to be specified by a set of principles shared by the bulk of mutual organizations and inherited of historical experience. The major part of these principles is also adopted by other social economy organizations:

- Absence of shares: mutuals are a grouping of persons (physical or legal), the members, and not a pooling of funds as in the case of corporations. Unlike cooperatives, whose capital is represented by shares, the funds of mutuals are owned 
and managed jointly and indivisibly. A mutual has no external shareholders to pay by dividends, and does not usually seek to maximize profits. Mutual organizations exist for the members to benefit from the services they provide; their main resource are the fees or premiums paid by their members/owners

- Free membership that means free entry (and free exit) for everyone who fulfils the conditions laid down in the by-laws and abides by mutualism principles. According to these conditions the mutual can be "open" to the population at large, such as health mutuals in Belgium or "closed", reserved to a geographical area, an industry or an occupation. In the case of compulsory insurance, health insurance or car insurance for example, the choice of the insurer has to be free.

- Solidarity among members, a historical principle rooted in the $19^{\text {th }}$ century worker's movement and the ideology of the solidarism current. To day, that means a joint liability and a cross subsidization between good risks and bad risks in mutual benefit society and no discrimination among members.

- Democratic governance, conveyed by the principle "one person, one vote" in opposition with the rule "one share, one vote" which is symbolic of the corporate governance. Board's members are volunteers, in opposition with the practice of the director fees of the corporations.

- Independence: mutuals are private and independent organizations, neither controlled by government representatives nor funded by public subsidies. In the absence of shares, a mutual cannot be subject to a takeover bid by a standard business.

- Limited profit sharing: the profit of a mutual can be shared among the owners/ members, usually as discounted premiums or rebates. The main part of the profit is reinvested in order to improve the services proposed to members, to finance the development of the business or to increase their own funds. Profit sharing has to be limited because it is not the aim of the organization. The aim of the organization is to meet the interests of the members and sometimes of the community at large and also to empower the members. The fact that profit sharing is authorized in mutual societies prevents most of them to be included in the nonprofit sector, strictly non profit distributing. However they belong to the larger social economy.

These principles often referred to as mutualism values are inherited of a deeply rooted historical background.

\section{HISTORICAL BACKGROUND}

Mutual benefit societies date back to the most ancient times while mutual insurance companies are more recent. Some precursory mutual organizations could be found in Ancient Egypt (mutual assistance among stone cutters) or in the Roman Empire (the same among bricklayers). However mutual benefit societies are mainly descendants of the oldest part of the European non-profit sector: they appeared in the Middle Ages as charitable brotherhoods (continental Europe) or friendly societies (United Kingdom). Brotherhoods were fraternal societies in urban areas linked to the guilds and therefore reserved to the same craft, business or trade. These organizations helped the needy members of the guild in the case of illness or their family, the widow and the orphan, in the case of death of the breadwinner; they served also as sociability and ceremonial places. Friendly societies fulfilled the same purposes but they were independent of the guilds and therefore more open than brotherhoods. The corporatist system, on which the guilds and brotherhoods relied, became weaker but survived with the rise of the free market and modern industry in most European countries. In France, the 1789 Revolution suppressed both guilds and their social subsidiaries, the brotherhoods. 
Nevertheless mutual benefit societies flourished during the 19th Century in Europe, when industrial revolution and rural depopulation pauperized the working class and broke the traditional solidarity of the family or the village. They were inspired by ideological currents such as utopist socialism (Owen, Proudhon), the Fabian movement or solidarism (Bourgeois, Durkheim). Some of these mutuals were linked with the emerging labor-unions and other were more middle-class oriented. Depending on the countries, the period and the degree of recognition of the labor movement, they were either repressed or encouraged by the state.

Whatever their form, mutual benefit societies were the forerunner of the welfare states. Mutual societies detected first the main social risks, sickness, disability and old age, that were covered later by a public social insurance scheme in Continental European countries and by a National Health service and pension funds in Anglo-saxon and Nordic countries. During the $20^{\text {th }}$ century, modern welfare states challenged mutual benefit societies, forced to become either complements or agents of the compulsory social security schemes. However most of them keep their vanguard function.

The forerunners of mutual insurance companies are more recent. They can be found in the second part of $19^{\text {th }}$ century when the progress of probabilistic mathematics transformed insurance in a modern industry. Farmers pooled their savings to protect themselves against the risks of their property, bad weather and fires mainly, on a mutual basis. Other mutual insurance companies for retailers and craftsmen followed, in competition with insurance corporations, but the dissemination of mutual insurance among the salaried population is more recent; it was in many countries a by-product of the post WWII consumption society, especially with the compulsory insurance of car accidents and other damage to real estate property.

The second part of $19^{\text {th }}$ century and the beginning of $20^{\text {th }}$ century is also the time when mutual forms of banking appeared in Europe either as mutual societies or cooperatives to pool the savings and afford credit to the part of the population who had no access to commercial banks because of their lack of guarantee. The Raiffeisen banks in Germany are the most emblematical, the savings and loans associations or the savings banks the most widespread.

\section{PANORAMA OF THE EUROPEAN MUTUAL ORGANIZATIONS AND INTERNATIONAL PERSPECTIVES}

\section{Europe}

Rooted in this long and diverse historical background, the European mutual organizations/ societies are to-day important providers of insurance and health services. Mutual insurance companies hold a very significant share of the insurance market: $50 \%$ of car and real estate insurance in France, $22 \%$ of the whole insurance industry in Germany but they are rare in Italy or Greece. Their market share in life insurance and pension funds is smaller but it is growing

There are mutual benefit societies in every European country and all of them provide health insurance and other services. They are for historical reasons tightly linked to the social security schemes but their role differ according to the form of the health protection: social insurance, funded by employers and employees contributions, in most continental and oriental countries (Bismarckian scheme) or National Health services financed by tax in Anglo-saxon, Nordic and some Mediterranean countries (Beveridgian scheme). According to these various 
social protection schemes, mutual benefit societies either run the compulsory health insurance (Germany, Belgium, Netherlands, Czech Republic, Slovaquia) or provide a complementary sickness or old age insurance (France, Switzerland, Luxemburg Spain, Portugal) or alternatives to the National Health System, such as quicker health care or higher pensions (UK and Nordic countries). Mutual benefit societies cover a larger part of the population in the Bismarckian than in the Beveridgian countries, as showed in Table1.

Table 1. Distribution of the population covered by a mutual benefit society in Europe

\begin{tabular}{|c|c|c|c|c|}
\hline $\begin{array}{l}\text { Less than } 20 \% \text { of } \\
\text { total population }\end{array}$ & $\begin{array}{l}20 \% \text { to } 40 \% \text { of } \\
\text { total population }\end{array}$ & $\begin{array}{l}40 \% \text { to } 60 \% \text { of } \\
\text { total population }\end{array}$ & $\begin{array}{l}60 \% \text { to } 80 \% \text { of } \\
\text { total population }\end{array}$ & $\begin{array}{l}80 \% \text { to } 100 \% \text { of } \\
\text { total population }\end{array}$ \\
\hline $\begin{array}{l}\text { Italy } \\
\text { Greece } \\
\text { Spain } \\
\text { United Kingdom } \\
\text { Portugal }\end{array}$ & $\begin{array}{l}\text { Hungary } \\
\text { Denmark } \\
\text { Sweden } \\
\text { Finland }\end{array}$ & $\begin{array}{l}\text { Slovakia } \\
\text { Slovenia } \\
\text { Ireland }\end{array}$ & $\begin{array}{l}\text { France } \\
\text { Czech Republic } \\
\text { Luxemburg }\end{array}$ & $\begin{array}{l}\text { Germany } \\
\text { Netherlands } \\
\text { Belgium } \\
\text { Switzerland }\end{array}$ \\
\hline
\end{tabular}

Source: Association internationale de la mutualité

However in Europe, mutual organizations do not extend to other industries than their historical ones: property, personal and social insurance or credit. That is why they are the smaller part of social economy organizations. Table 2 gives only an order of magnitude of the respective part of cooperatives, mutuals and associations/ foundations in social economy. Even if these data are not strictly comparable because they not based on a common methodology, employment in mutual organizations is only 3.5 per cent of the total employment in social economy organizations, compared to 29 per cent in cooperatives and 68.5 per cent in nonprofit organizations.

Table 2 Employment in mutual societies and other social economy organisations, EU 15

\begin{tabular}{|l|l|l|l|l|l|}
\hline Countries & Cooperatives & $\begin{array}{l}\text { Mutual } \\
\text { societies }\end{array}$ & $\begin{array}{l}\text { Associations } \\
\mathbf{d}\end{array}$ & $\begin{array}{l}\text { Total } \\
\text { Foundations } \\
\text { Ecial } \\
\text { Economy }\end{array}$ & $\begin{array}{l}\text { Social } \\
\text { Economy as } \\
\text { of total } \\
\text { paid } \\
\text { employment, } \\
\mathbf{2 0 0 2}\end{array}$ \\
\hline Germany & 466900 & 150000 & 1470000 & 2086900 & 5.9 \\
\hline Austria & 61830 & 8000 & 190000 & 259830 & 7.9 \\
\hline Belgium & 1077 & 11230 & 161860 & 174167 & 5.0 \\
\hline Denmark & 39107 & 1000 & 120657 & 160764 & 6.2 \\
\hline Spain & 439618 & 3548 & 380060 & 823226 & 5.6 \\
\hline Finland & 95000 & 5405 & 74992 & 175397 & 8.5 \\
\hline France & 441950 & 115100 & 1435330 & 1992380 & 8.7 \\
\hline Greece & 14304 & 489 & 57000 & 71793 & 3.0 \\
\hline Ireland & 35992 & 650 & 118664 & 155306 & 10.6 \\
\hline Italy & 837024 & - & 499389 & 1336413 & 7.5 \\
\hline Netherlands & 171775 & - & 661400 & 833175 & 11.6 \\
\hline Portugal & 51000 & - & 159950 & 210950 & 5.5 \\
\hline UK & 215072 & 47818 & 1473000 & 1735890 & 7.1 \\
\hline Sweden & 52117 & 8000 & 95197 & 155314 & 3.8 \\
\hline EU 15 & $\mathbf{2 9 2 4 0 0 0}$ & $\mathbf{3 4 5 0 0 0}$ & $\mathbf{6 9 0 3 0 0 0}$ & $\mathbf{1 0 1 7 2 0 0 0}$ & $\mathbf{6 . 3}$ \\
\hline
\end{tabular}




\section{International perspectives}

In the United States many insurance companies were initially mutual insurance; more some corporations mutualized, their ownership passing to their policy owners. But as said further, the reverse trend of demutualization occurred in the 1980s. Nowadays, even if their name includes the term mutual, all insurance companies are joint stock owned. Many savings and loan associations were also mutual companies, owned by their depositors, but most of them are now under stock ownership. In the same way, some health insurance companies, formerly created as nonprofit organizations, such as Blue Cross and Blue Shield, became under the pressure of competition more standard businesses; especially they discriminate among their clients health risks, a forebidden behaviour in European mutual benefit societies.

Nowadays, in many developing countries where public social insurance does not exist or is at the very beginning, mutual organizations play the same role than the mutual benefit societies in the European countries in $19^{\text {th }}$ century, especially in Latin America, Asia or Africa. These mutuals begin as in Europe formerly, by the most organized and educated part of the population. The risks covered are illness, death and accident and also mutual help in case of social events such as marriages and funerals that are proportionally much more costly than in developed countries. Most of these mutual organizations were created during the last two decades and they are a source of empowerment for the population. For example the Fandene mutuals in Senegal are controlled by elected countrymen of the same village; in Bolivia, Projecto de Salud provides free health care in exchange of volunteer work to build the health facilities; in Philippines, Mother and Child Care relies on members fees but acts also as a lobby to obtain low prices from the multinational drugs companies. When public health insurance or health service is created, mutual organizations shift to other risks such as old age. Mutual organizations such as the tontines are also widespread in developing countries. Tontines pool the savings among a small group of members or a village; a random winner every year takes all the money to realize a small business; the tontine's life ends when every member has got once the pooled savings. These financial mutuals look like the building societies of the earliest times

\section{KEY ISSUES}

\section{Competition}

Mutual insurance companies compete with investor-driven businesses. In this competition they have advantages and disadvantages. Some features can be put on the asset side:

- The mutuals rely on trust, a winning card in an industry with high information asymmetry as Hansmann shows it: the insurer knows more than the client on the probability of the risk but the client knows more on the quality of the car or dwelling insured. Trust in mutual insurance companies is manifested by a lower discrimination among members than in the competing businesses and by the education of their members to prevent the risks and not to cheat in their accident claims.

- They have a better quality price ratio than their competitors due to their nearly nonprofit status, to their policy of rebates, to the fact that they have no or few brokers and also to the homogeneity of their members in the case of professional mutuals

- They have a high financial solidity, because their investments are less risky and more often ethical than those of their competitors and also because they are not subject to take-over bids. In the periods of stock exchange crisis, they act as stabilizing agents 
and shock absorbers. This financial stability incite mutual insurance companies to have long term objectives

But the shortcomings of the mutual status exist also:

- The mutual insurance companies have a limited access to external capital from the financial markets while thee restricted voting rights may also discourage external investors. This limited access to external capital is an obstacle to life insurance, an activity that cannot be run with a pay as you go system as the property insurance. In the latter the premiums are devoted to the members who had a loss on an annual basis

- The size of some of the big mutual insurance societies is likely to distance members from the decision-making centre. In the smaller ones, the application of democratic governance may lead to delays in the decision-making process. Recently, the application to mutual insurance companies of the European directives on insurance incited them to merge to attain a critical size on the insurance market.

These disadvantages facing competition lead recently many Anglo-Saxon countries to a demutualization trend

\section{Demutualization}

In the United Kingdom, the demutualization of the Building Societies was the beginning of a wave of demutualization as part of the Thatcher's government deregulation trend. The building societies first arose in the 19th century from working men's mutual savings groups: by pooling their savings, members could buy or build their own homes. With the development of financial services, building societies offered mortgage loans as standard banks. In order to diversify their services to keep up with banks and other financial institutions in the commercial world the old societies needed to expand. To do that, they have to raise capital, a difficult operation with a mutual form because they have no access to equity markets. In 1986, the building societies became joint stock societies, the British form of corporations, and therefore they floated on the stock exchange. The capital and reserve funds were distributed among members who became shareholders. Of course sharing the collective property of these mutual organizations accumulated by many generations was a windfall gain for the present members who received each about $\$ 1000$. But the rising of costs and prices which followed the demutualization was an unexpected consequence for consumers and the bankrupt of Northern Rock, a former building society, during the subprime crisis was also a disillusion.

A major demutualization wave took place in the USA in the 1980s and again in the late 1990s according to the same line and a smaller one in Australia. This demutualization trend affected savings and loans association in the USA and building societies in Australia. Demutualization was less pronounced in continental Europe and it is forbidden by law in some countries such as France, Luxemburg or Ireland. In those countries who insist on the intergenerational nature of solidarity, the registered capital and the reserve funds cannot be shared among the members/owners if the organization disappears. In this case, the property of the organization has to be transferred to another mutual or social economy organization or to the state.

\section{Mutual benefit societies in changing welfare states}

Mutual benefit societies compete with health complementary insurance provided by standard insurance companies. In this competition to money transfers or reimbursements, they keep or extend their market shares in most countries as they have a better quality/cost ratio. Health mutuals rely on principles which are different of commercial insurance companies: fees are paid according to the member's income and not according to its personal risk or its age. Bad 
risks are never rejected, there is no rate and benefit discrimination among members and therefore a cross-subsidization between bad and good risks and rich and poor occurs

However mutual benefit societies are much more challenged by the retrenchment or change of the public welfare states when the demand for social services increases. Two long-term trends, the ageing of the population and the reduction of care self-service inside households due to the growth of female employment, rise the demand of day care, homecare and nursing homes. Facing what Esping-Andersen called the "defamilialisation" or "family failure" of care services, during the last decades, mutual benefit societies in some European countries provided social services or facilities to the children, the disabled and the frail elderly, with high quality standards. In the social homecare service provision, they compete with standard businesses and also with nonprofit organizations. These personal services are financed partly by the household itself, partly by the central and local governments or social security, partly by the employers. Nordic and Anglo-saxon countries are the forerunners in this new welfare mix spreading rapidly elsewhere.

\section{FUTURE DIRECTIONS}

\section{European mutual societies at the cross-road}

Mutual societies are driven by two logics, insurance and solidarity, the former dominates in insurance mutual companies and the later in mutual benefit societies. This frail equilibrium is nowadays challenged by the European Commission ambiguous guidelines. In one hand the European Commission acknowledges the public benefit role of mutual societies and other social economy organizations. In the other hand, the insurance directive and the Solvability 2 guideline consider them as insurance corporations and incite them to a kind of standardization. More, the status of European mutual society that was drafted to make the cross-country collaboration of mutuals easier is no more at the agenda.

Another challenge is due to the merging trend in mutuals, partly a consequence of European guidelines. This horizontal integration increases the size of mutual societies with the result of more difficult democratic governance, with elected representatives of the owners/members. Many mutuals created also corporate subsidiaries, another way of trivialization or institutional isomorphism.

\section{Mutual societies are fitted with post-industrial societies}

Mutual societies are prototypes of social enterprises, an emerging form of enterprise. In postindustrial societies, personal services, difficult to standardize, offering a wide range of quality and asymmetric information are able to be provided by mutual as well as nonprofit organizations. A democratic management fits the well educated youth who dislikes the authoritarianism of standard firms and advocates the social responsibility of enterprise. A mutual form fits also high technology services at least at their very beginning, when partners are supposed equal: the wiki movement for example shows it. A mutual could also run pension funds with a better financial solidity and a more ethical choice of investments than for-profit pension funds. So in the future, pre-industrial forms of mutual in developing countries could coexist with post-industrial forms, well adapted to the knowledge economy. 


\section{SEE ALSO}

- Cooperatives

- Cross-subsidization

- Empowerment

- Information asymmetry

- Solidarity

- Social economy

- Volunteer management

- Durkheim

- Hansmann

- Proudhon

\section{REFERENCES}

Archambault E (1997). The Nonprofit sector in France. Manchester, Manchester University Press

Association internationale de la mutualité (AIM), http://www.aim-mutual.org, 15/03/2008

Association internationale des sociétés d'assurance mutuelle (AISAM) http://www. aisam.org/, 12/03/2008

Chaves R. and Monzon Campos J-L (2007), The social economy in the European Union, CIRIEC Report to the European Economic and Social Committee, $N^{\circ}$ CESE/COMM/05/2005

Defourny J., Develtere P. and Fonteneau B. (1999), L'économie sociale au Nord et au Sud, Brussels, De Boeck

Dreyfus M. (1993), "The labour movement and mutual benefit societies. Towards an international approach". International Social Security Review. 46:3, 19-27

European Commission, Enterprise Directorate General (2003), Mutual Societies in an Enlarged Europe, Consultation Document, 03/10/2003

Esping-Andersen G.(1999), Welfare states in Transition: National Adaptations in Global Economies, London: Sage publications.

Noya A. and Clarence E. (2007), The social economy. Building inclusive economies, Paris: OECD publishing

Salamon L. and Anheier H. (1997), Defining the Nonprofit Sector: A Cross-national Analysis, Manchester: Manchester University Press 
